\title{
Morphological and molecular description of Allocreadium apokryfi sp. n. (Digenea: Allocreadiidae) from native Labeobarbus aeneus (Cyprinidae) in South Africa, including notes on its biology, evolutionary history and an updated key of African Allocreadium
}

\author{
${ }^{1}$ Department of Zoology, University of Johannesburg, Johannesburg, South Africa \\ ${ }^{2}$ Spectrum Analytical Facility, University of Johannesburg, Johannesburg, South Africa \\ ${ }^{3}$ Department of Biological Sciences, Eduardo Mondlane University, Maputo, Mozambique
}

Quinton M. Dos Santos ${ }^{(1)}{ }^{1}$, Beric M. Gilbert ${ }^{(1,2}{ }^{1,2}$, Annemariè Avenant-Oldewage $\mathbb{D}^{1}$ and José C. Dumbo $\mathbb{D}^{1,3}$

\begin{abstract}
Adult trematodes of Allocreadium Looss, 1900 (Digenea) infect the intestine of mostly freshwater fishes in Asia, Europe, Africa and the Americas. During routine parasitological surveys in the Vaal River system, adult trematodes were collected from the intestine of smallmouth yellowfish, Labeobarbus aeneus (Burchell). The trematodes were confirmed to represent a member of Allocreadium and did not match any existing taxon. Therefore, they are described as a new species, Allocreadium apokryfi sp. n. The morphology of the new species most closely resembles that of Allocreadium aswanense El-Naffar, Saoud et Hassan, 1984, but it differs from it by having a bipartite internal seminal vesicle, wider eggs, a shorter intertesticular distance, an intestinal bifurcation at the ventral sucker level, a ventral sucker that is larger than the oral sucker, and a genital pore near the intestinal bifurcation or the ventral sucker. The surface topology of the new species is notably different from that of other allocreadiids. Papillae were observed in the ventral sucker and surrounding both ventral and oral suckers, but the number and arrangement of the latter were not consistent among specimens. The protruding cirrus of $A$. apokryfi sp. n. was described using SEM and is the first such observation for the genus. Genetic characterisation showed that the new species was clearly distinct from other Allocreadium spp. using both 18S (nucleotide difference 1.3-9.1\%) and 28S (4.7-6.5\%) rDNA, forming a well-supported clade in Allocreadium. The presence of A. apokryfi sp.n. in a well-studied river is unexpected, and considering the diet of its host and the scarcity of Allocreadium in Africa, the possible biology of this species is discussed herein.
\end{abstract}

Key words: Smallmouth yellowfish, endoparasitic helminths, Trematoda, Africa, 28S rDNA, 18S rDNA, SEM, taxonomic key.

The trematode genus Allocreadium Looss, 1900 includes small to medium-sized parasites inhabiting the digestive tract of a remarkable range of mostly freshwater fish families (Caira and Bogéa 2005). Adults have an elongated, dorsoventrally flattened body, well-developed pharynx and suckers, testes in tandem, vitellarium extending from the forebody at various levels to the posterior end of the body, with vitelline follicles in two lateral fields anteriorly but confluent posteriorly (Caira and Bogéa 2005).

The genus Allocreadium has been speculated to have originated in southern Asia, spread into Eurasia, then North America, and to some extent into Africa, with African species having affinities to Indian taxa (Thomas 1957, Manter 1963). Recently, species have also been described from South America (Shimazu et al. 2000, Flores et al. 2004). All species of the genus are strictly from freshwater envi- ronments (Manter 1963, El-Naffar 1986), and no species have been recorded from more than one continent. This indicates that the evolution and spread of species of this genus may be useful in indicating intercontinental connections (Manter 1963). Delineation among species of the genus is based on adult morphology (i.e., sucker size, ovary position, vitellarium distribution, oesophagus length, pharynx size, genital pore position, extent of intertesticular space, and host range) (Thomas 1957, Saoud et al. 1974).

Systematics of the genus has been problematic due to taxonomy being based predominantly on morphometry and a lack of genetic studies (Vainutis 2020). It would appear that a high level of intraspecific variability exists among species of this genus, which has resulted in many species being relegated to synonymy (see Peters 1957 , Kakaji 1969). Thomas (1957) accepted 30 species, whereas 


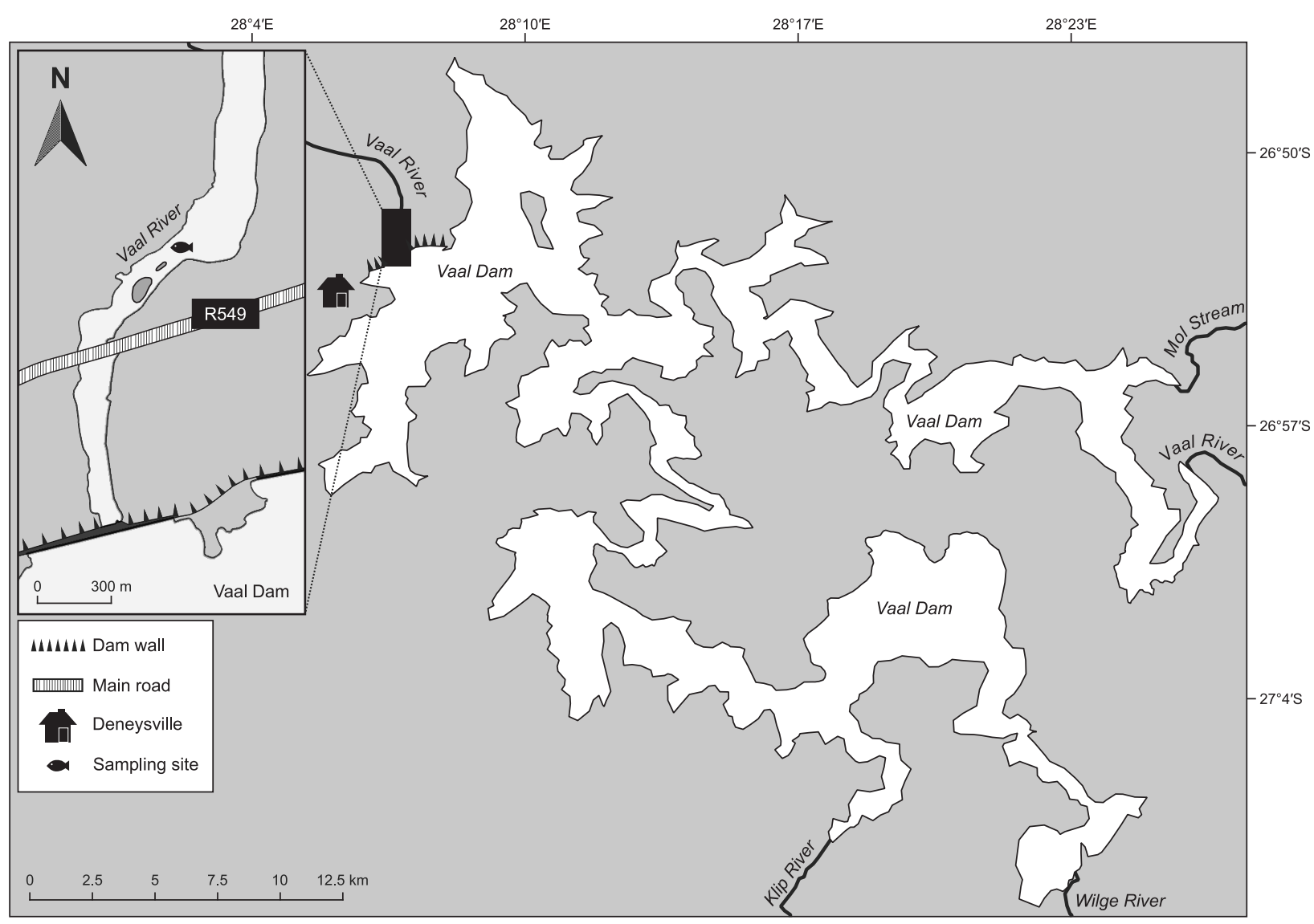

Fig. 1. Map of the sample collection site in the Vaal River below the Vaal Dam, South Africa. Insert shows the specific sampling site for Labeobarbus aeneus (Burchell) in the Vaal River.

Peters (1957) in a review based on morphological features of cercariae retained 16 of the 31 species described at the time. In contrast, Saoud et al. (1974) accepted 45 species. Currently, the literature on species of the genus Allocreadium reveals large species diversity (e.g. WoRMS 2020), mostly described from Asia, Europe, Africa and the Americas (Vainutis 2020).

Eight species were described from Africa: Allocreadium voltanum Thomas, 1957; Allocreadium indistinctum Baer, 1959; Allocreadium mazoense Beverley-Burton, 1962; Allocreadium ghanense Fischthal et Thomas, 1972; Allocreadium engraulicypridis Khalil et Thurston, 1973; Allocreadium sudanense Saoud, Abdel-Hamd et Ibrahim, 1974; Allocreadium aswanense El-Naffar, Saoud et Hassan, 1984; and Allocreadium bynni El-Naffar, 1986. These species have been described from hosts in the families Cyprinidae, Alestidae, Clariidae and Mochokidae (Thomas 1957, Baer 1959, Beverley-Burton 1962, Fischthal and Thomas 1972, Khalil and Thurston 1973, Saoud et al. 1974, El-Naffar et al. 1984, El-Naffar 1986). However, while Asian species of the genus are frequently encountered in many regions (Gao et al. 2008), they seem to be quite scarce in Africa (Mbahinzireki 1987). This is supported by the large gaps between some of the most recent records of Allocreadium in Africa in 1987 and 2010 (Mbahinzireki 1987, Mwita and Nkwengulila 2010), with the current record more than a decade later.
In the current study, digeneans belonging to Allocreadium were collected from the intestine of Labeobarbus aeneus (Burchell) in the Vaal River, South Africa. Trematodes of this group have not been recorded from this host nor locality previously, and were studied using an integrative taxonomic approach involving morphological data (light and scanning electron microscopy) in combination with DNA characterisation. The parasites showed morphometric and molecular traits that set them apart from congeneric taxa described in Africa, as well as in the rest of the world, and as such were designated as a new species. A key for African species of Allocreadium is provided, based on the revised and updated key by El-Naffar (1986).

\section{MATERIALS AND METHODS}

\section{Sample collection}

Smallmouth yellowfish, Labeobarbus aeneus, were collected in November 2019 using gill nets and electrofishing approximately $1.5 \mathrm{~km}$ downstream of the wall of the Vaal Dam (Fig. 1) in the Vaal River $\left(26.871111^{\circ} \mathrm{S}, 28.118611^{\circ} \mathrm{E}\right)$. Fish were euthanised by severing the spinal cord posterior to the skull, the intestinal tract was removed and examined for the presence of parasites. Intestines were opened carefully in saline with fine forceps using a dissection microscope and trematodes removed using a 000 Camel's hair paintbrush. For morphological study, trematodes were fixed in warm $10 \%$ neutral buffered formalin or warm $70 \%$ etha- 
nol using a temporary mount (coverslip suspended on dollops of petroleum jelly) to prevent specimens from folding. Additionally, some specimens were fixed in $70 \%$ ethanol for scanning electron microscopy (SEM) study or $96 \%$ ethanol for molecular study at room temperature. Infection parameters were calculated according to Bush et al. (1997). Fish were collected and sacrificed in accordance with permit CPE2-0118 from the Nature Conservation of Gauteng Province Government, South Africa and ethics reference 2016-5-03 from the University of Johannesburg. All institutional and national guidelines for the collection and study of fish were followed.

\section{Light microscopy}

For whole mount preparations, ovigerous adult specimens $(\mathrm{n}=19)$ were stained with acetocarmine, differentiated in $0.5 \%$ acid alcohol, dehydrated in a graded ethanol series, cleared in beechwood creosote, and mounted in Canada balsam (Thatcher 2006). Photomicrographs and measurements were obtained with an Olympus BX53 compound microscope and Olympus Soft Imaging Solutions (Olympus, Münster, Germany), then used for illustrations with Corel DRAW ${ }^{\circledR}$ Graphics Suite X6 software (Corel Corporation, Ottawa, Canada). All measurements pertain to specimens fixed using a temporary mount and are given in micrometres unless otherwise stated, given as the range followed by the mean in parentheses. All measurements (including standard deviation) are given alongside those of all other African Allocreadium spp. as per their original descriptions in Table 1.

\section{Scanning electron microscopy}

Seven whole specimens fixed in $70 \%$ ethanol were prepared for SEM study by dehydration through a graded ethanol series, followed by a graded series of hexamethyldisilazane (Merck, Darmstadt, Germany) (Nation 1983, Dos Santos et al. 2015). Specimens were dried in a Sanpla dry keeper desiccator cabinet (Kita-Ku, Osaka, Japan) and coated with gold using an Emscope SC500 sputter coater (Quorum Technologies, Newhaven, UK). A Vega 3 LMH scanning electron microscope (Tescan, Brno, Czech Republic) was used to study the specimens at 5-6 kV. Microdissection of dried specimens was also used to study eggs in utero.

\section{Genetic study}

Genomic DNA was extracted from five whole trematodes using a NucleoSpin ${ }^{\circledR}$ Tissue Kit (Macherey-Nagel, Düren, Germany) following the manufacturer's instructions. The D1-D3 region of 28S rDNA was amplified with primers dig12 (5' - AAG CAT ATC ACT AAG CGG - 3') (Tkach et al. 2003) and 1500R (5' GCT ATC CTG AGG GAA ACT TCG - 3') (Olson et al. 2003, Tkach et al. 2003), while 18S rDNA was amplified with JLR24 (5' - CGG AAT TCG CTA GAG GTG AAA TTC TTG G - 3') and JLR25 (5' - CCG AAT TCC GCA GGT TCA CCT ACG G - 3') (Campos et al. 1998). PCR conditions were adjusted from Tkach et al. (2003) for 28S rDNA (initial denaturation 5 minutes, final elongation 10 minute and annealing temperature $52{ }^{\circ} \mathrm{C}$ ), and Mwita and Nkwengulila (2010) for $18 \mathrm{~S}$ rDNA (annealing temperature $50{ }^{\circ} \mathrm{C}$ ). Successful amplification was verified using a $1 \%$ agarose gel, impregnated with GelRed ${ }^{\mathrm{TM}}$ (Biotium Inc., Fremont City, California), and visualised with a UV transilluminator. Sequencing was done according to Avenant-Oldewage et al. (2014) using PCR primers in both directions.
Generated sequence data were aligned, inspected, edited if necessary, and reads merged using Geneious Prime 2020.2.2 (Kearse et al. 2012). To determine the distinctness of the trematodes, obtained sequences were analysed using BLAST (Altschul et al. 1990) and aligned to all previously published Allocreadium $18 \mathrm{~S}$ and 28S rDNA sequences (and Palaeorchis [Cercariaeum] crassus [Wesenburg-Lund, 1934]) downloaded from GenBank (details in Table 2) using MEGA7 (Kumar et al. 2016) and MAFFT (Katoh et al. 2002, Katoh and Standley 2013). Pairwise distances were estimated by uncorrected $p$-distance with 1,000 bootstrap replicate variance estimation using MEGA7.

Evolutionary history was studied using 28S rDNA, employing both maximum likelihood (ML) and Bayesian inference (BI) methods. For ML analyses, the General Time Reversible model (GTR) (Nei and Kumar 2000) with discrete Gamma distribution $(5$ categories $(+\mathrm{G}$, parameter $=0.4408)$ ) was selected as the best nucleotide substitution model using MEGA7. This was supported by 1,000 bootstrap replicates. Bayesian inference analyses were performed with BEAST v2.5.0 (Bouckaert et al. 2014) using 10 million Markov chain Monte Carlo (MCMC) generations and the GTR model. Due to the similarity between BI and ML analyses, a single topology based on BI analyses is given with both ML and $\mathrm{BI}$ support indicated at respective nodes and rooted with both $\mathrm{Ac}$ rolichanus auriculatus (Wedl, 1858) (MN750364) and Crepidostomum oschmarini Zhokhov et Pugacheva, 1998 (MH159994) as outgroup.

\section{RESULTS}

Allocreadium apokryfi sp. n.

Figs. 2-5

ZooBank number for species:

urn:1sid:zoobank.org:act: 97514610-93E3-473E-900F-BBB35068F5A8

Description (based on 19 whole mounts of gravid trematodes and 7 whole trematodes examined with SEM). Body elongate $1.75-3.33 \mathrm{~mm}$ (2.74 mm) long, 622-1.030 (846) wide, rounded anteriorly, tapering towards posterior, widest at level of ventral sucker (Figs. 2A, 3A). Both suckers well-developed. Oral sucker anterior, ventrally subterminal, subspherical, 212-338 (256) long, 146-355 (254) wide (Figs. 2A, 3B). Ventral sucker subspherical, wider than long, 247-349 (299) long, 254-350 (310) wide (Figs. 2A, 3C). Tegumental papillae present in both oral and ventral suckers. Papillae at oral sucker present inside oral opening, around rim of sucker (in two rows), and more distant from opening (Fig. 3B). The number and placement of papillae inconsistent among specimens. Sensory openings present on anterior rim of oral sucker (Fig. 3B and insert). Ventral sucker with 4 to 6 tongue-like papillae on inner lip, with additional papillae present around ventral sucker of some specimens (Fig. 3C). Tegument aspinous (Figs. 3, 4), transverse striations observed on some specimens, generally more striking in ventral part of forebody (Figs. 3A, 4A), dissipating posteriorly (Figs. 3A, 4B), absent on dorsal body surface (Fig. 4D). Cobblestone-like protrusions intermittently present at high magnification (Fig. 4C). Eye spot pigment not observed. Oral sucker unarmed; mouth opens directly to pharynx (Fig. 3B). Prepharynx absent. 
Table 1. Measurements (in $\mu \mathrm{m}$ unless otherwise stated) of adult Allocreadium apokryfi sp. n. (values in bold) and all other species of Allocreadium Looss, 1900 described from Africa.

\begin{tabular}{|c|c|c|c|c|c|c|c|c|c|}
\hline Species & A. voltanum & A. indistinctum & A. mazoense & A. ghanense & $\begin{array}{l}\text { A. engrau- } \\
\text { licypridis }\end{array}$ & A. sudanense & A. aswanense & A. bynni & Allocreadium n. sp. \\
\hline Locality & West Africa & Congo & Zimbabwe & Ghana & Uganda & Sudan & Egypt & Egypt & South Africa \\
\hline Reference & $\begin{array}{l}\text { Thomas } \\
\text { (1957) }\end{array}$ & Baer (1959) & $\begin{array}{c}\text { Beverley- } \\
\text { Burton (1962) }\end{array}$ & $\begin{array}{c}\text { Fischthal } \\
\text { and Thomas } \\
(1972)\end{array}$ & $\begin{array}{l}\text { Khalil and } \\
\text { Thurston } \\
\text { (1973) }\end{array}$ & $\begin{array}{l}\text { Saoud et } \\
\text { al. (1974) }\end{array}$ & $\begin{array}{l}\text { El-Naffar et } \\
\text { al. (1984) }\end{array}$ & $\begin{array}{c}\text { El-Naffar } \\
\text { (1986) }\end{array}$ & Present study \\
\hline Body length (mm) & $4.51-7.12$ & $0.875-1.04$ & $1.69-2.62$ & $2.88-3.26$ & $2.04(2.32)^{\mathrm{b}}$ & $2.89-3.71$ & $2.24-4.56$ & $2.20-3.40$ & $1.75-3.33(2.74 \pm 0.37)$ \\
\hline Body width & $1,440-1,710$ & $390-455$ & $650-980$ & $900-940$ & $880(1,020)^{\mathrm{b}}$ & $920-1,330$ & $880-1,330$ & $990-1200$ & $622-1,030(846 \pm 118)$ \\
\hline Forebody length & - & - & - & $1,110-1,155$ & - & - & - & $640-810$ & $382-995(697 \pm 140)$ \\
\hline Hindbody length (mm) & - & - & - & $1.35-1.68$ & - & - & - & $1.15-1.76$ & $1.13-2.35(1.74 \pm 0.28)$ \\
\hline Prepharynx length & - & - & - & $26-50$ & - & - & - & - & - \\
\hline Oesophagus length & - & - & 270 & 95-135 & - & - & $330-560$ & $66-92$ & $114-724(488 \pm 148)$ \\
\hline Pharynx length & $150-220$ & 105 & $120-150$ & $200-220$ & $130(140)^{\mathrm{b}}$ & $160-210$ & $110-200$ & $95-125$ & $100-166(130 \pm 21)$ \\
\hline Pharynx width & $140-190$ & 91 & $90-160$ & 150 & $170(170)^{\mathrm{b}}$ & $140-160$ & $140-170$ & $98-129$ & $114-174(143 \pm 18)$ \\
\hline Oral sucker length & $300-380$ & $229-250$ & $190-280$ & $400-420$ & $300(330)^{\mathrm{b}}$ & $320-390$ & $260-380$ & $370-400$ & $212-338(256 \pm 37)$ \\
\hline Oral sucker width & $370-410$ & - & $220-300$ & $410-420$ & $300(330)^{\mathrm{b}}$ & $360-380$ & $330-390$ & $400-470$ & $146-355(254 \pm 43)$ \\
\hline Ventral sucker length & $400-530$ & $274-320$ & $230-320$ & $420-460$ & 450 & $400-460$ & $320-390$ & $380-410$ & $247-349(299 \pm 29)$ \\
\hline Ventral sucker width & $450-600$ & $69-90$ & $260-360$ & $480-520$ & 410 & $360-470$ & $290-390$ & $440-480$ & $254-350(310 \pm 31)$ \\
\hline Ovary length & $200-250$ & $114-123$ & $210-250$ & $120-150$ & $180(190)^{\mathrm{b}}$ & $300-320$ & $190-310$ & $150-230$ & $152-250(199 \pm 26)$ \\
\hline Ovary width & $190-270$ & $114-123$ & $190-270$ & $150-160$ & $120(140)^{\mathrm{b}}$ & - & $150-250$ & $130-210$ & $161-252(201 \pm 26)$ \\
\hline Anterior testis length & $400-500$ & 183 & $220-300$ & $300-330$ & $230(290)^{\mathrm{b}}$ & $470-630$ & $330-480$ & $340-410$ & $228-438(308 \pm 52)$ \\
\hline Anterior testis width & $650-780$ & $142-160$ & $140-300$ & 320 & $170(210)^{\mathrm{b}}$ & $480-550$ & $330-420$ & $330-440$ & $201-379(296 \pm 48)$ \\
\hline Posterior testis length & $500-570$ & 183 & $270-330$ & $350-450$ & $220(330)^{\mathrm{b}}$ & $420-480$ & $330-440$ & $340-520$ & $241-592(364 \pm 76)$ \\
\hline Posterior testis width & $600-670$ & $142-160$ & $170-320$ & $250-270$ & $180(260)^{\mathrm{b}}$ & $470-490$ & $360-440$ & $340-480$ & $201-382(302 \pm 55)$ \\
\hline Egg length & $82.5-85$ & $100-110$ & $88-95$ & $90-101$ & 104 & $82-94$ & $70-80$ & $84-90$ & $83-92(87 \pm 3)$ \\
\hline Egg width & 60 & $55-64$ & $56-60$ & $55-64$ & 61 & $53-59$ & $30-40$ & $55-62$ & $60-74(66 \pm 4)$ \\
\hline Seminal receptacle length & $330-360$ & - & - & $230-330$ & 112 & $270-290$ & $160-280$ & $230-280$ & $86-256(173 \pm 51)$ \\
\hline Seminal receptacle width & $110-180$ & - & - & $120-210$ & 85 & $180-190$ & $80-120$ & $90-100$ & $79-160(113 \pm 25)$ \\
\hline Cirrus-sac length & $220-310$ & $274-320$ & $260-300$ & $360-450$ & 154 & $510-540$ & $440-670$ & $570-740$ & $480-754(602 \pm 72)$ \\
\hline Cirrus-sac width & $180-270$ & $69-91$ & $160-190$ & $120-130$ & 112 & $290-330$ & $110-240$ & $270-330$ & $137-261(187 \pm 28)$ \\
\hline Previtelline distance $(\mathrm{mm})$ & - & - & - & - & - & - & - & - & $0.72-1.72(1.19 \pm 0.25)$ \\
\hline Vitelline field length (mm) & - & - & - & - & - & - & - & - & $0.91-1.88(1.56 \pm 0.23)$ \\
\hline Vitelline follicle length & - & - & - & - & - & 130 & - & - & $89-152(121 \pm 19)$ \\
\hline Vitelline follicle width & - & - & - & - & - & 130 & - & - & $78-129(95 \pm 15)$ \\
\hline Ventral sucker to ovary distance & - & - & - & $0-27$ & - & - & - & - & $0-580(114 \pm 141)$ \\
\hline Ovary to anterior testis distance & - & - & - & $0-60$ & - & - & - & - & $10-402(194 \pm 100)$ \\
\hline Intertesticular distance & 0 & 0 & 0 & 0 & 0 & 0 & $30-170$ & 0 & $0-82(26 \pm 26)$ \\
\hline Post-testicular distance & - & - & - & $410-640$ & - & - & - & - & $481-922(708 \pm 102)$ \\
\hline Postvitelline distance & - & - & - & - & - & - & - & - & $46-122(87 \pm 25)$ \\
\hline Oral sucker length $(\%)^{\mathrm{a}}$ & - & - & - & - & - & - & - & - & $7-13(9 \pm 2)$ \\
\hline Ventral sucker length $(\%)^{\mathrm{a}}$ & - & - & - & - & - & - & - & - & $8-15(11 \pm 2)$ \\
\hline Oral to ventral sucker-length ratio & - & - & - & $1: 1.05-1.10$ & - & - & - & - & $0.70-1.12(0.85 \pm 0.14)$ \\
\hline Oral to ventral sucker-width ratio & - & - & - & $1: 1.12-1.24$ & - & - & - & - & $0.44-1.1(0.82 \pm 0.13)$ \\
\hline Forebody $(\%)^{\mathrm{a}}$ & - & - & - & - & - & - & - & - & $19-32(25 \pm 3)$ \\
\hline Hindbody $(\%)^{\mathrm{a}}$ & - & - & - & - & - & - & - & - & $51-71(63 \pm 4)$ \\
\hline Previtelline distance $(\%)^{\mathrm{a}}$ & - & - & - & - & - & - & - & - & $37-59(43 \pm 6)$ \\
\hline Ventral sucker to ovary dist. $(\%)^{\mathrm{a}}$ & - & - & - & - & - & - & - & - & 0-17 (4 \pm 4$)$ \\
\hline Cirrus-sac length $(\%)^{\mathrm{a}}$ & - & - & - & - & - & - & - & - & $16-26(21 \pm 3)$ \\
\hline Intertesticular distance $(\%)^{\mathrm{a}}$ & - & - & - & - & - & - & - & - & $0-3(0.9 \pm 0.9)$ \\
\hline Post-testicular distance $(\%)^{\mathrm{a}}$ & - & - & - & - & - & - & - & - & $22-30(26 \pm 2)$ \\
\hline Postvitelline distance $(\%)^{\mathrm{a}}$ & - & - & - & - & - & - & - & - & $1.6-6.8(3.3 \pm 1.3)$ \\
\hline Ovary length $(\%)^{\mathrm{a}}$ & - & - & - & - & - & - & - & - & $5.9-10(7.4 \pm 1.0)$ \\
\hline Vitelline field length (\%) ${ }^{\mathrm{a}}$ & - & - & - & - & - & - & - & - & $50-63(57 \pm 4)$ \\
\hline
\end{tabular}

Pharynx muscular, subspherical, smaller than oral sucker, 100-166 (130) long, 114-174 (143) wide, leading to long slightly curved oesophagus, 114-724 (488) long. Intestinal bifurcation at level of ventral sucker; intestinal caeca almost uniform in diameter throughout entire length, running into hindbody, terminate close to posterior end of body.

Testes two, oval in dorsoventral view, smooth, tandem, intercaecal, post-equatorial, separated by intertesticular distance 0-82 (26); anterior testis 228-438 (296) long, 201-379 (364) wide; posterior testis larger, 241-592 (364) long, 201-382 (302) wide; post-testicular distance 481-922 (708) (Figs. 2A). Cirrus-sac 480-754 (602) long, 137-261 (187) wide, retort-shaped, in forebody, situated near intestinal bifurcation, distal part of cirrus-sac reaching anterior to mid-level of ventral sucker, mostly medial, occasionally slightly overlapping ventral sucker, intercaecal, enclosing bipartite internal seminal vesicle, anterior part of cylindrical shape, posterior part large, looped, connecting to vas deferens (Fig. 2A,B). Protruding cirrus unarmed, tip blunt and flattened, lace-like texture on surface of protruded cirrus (Fig. 5A). Pars prostatica elliptical; prostatic gland cells spherical, thin-walled vesicular cells with nuclei. Ejaculatory duct forms widened part prior to opening into genital atrium. Vas deferens bifurcates at level of ovary into two vasa efferentia that connect to respective testes (Fig. 2C).

Ovary approximately oval, smooth in outline, generally smaller than testes, 152-250 (199) long, 161-252 (201) wide. Oviduct runs from anterior edge of ovary, connecting 
Table 2. List of allocreadiid trematodes included in the molecular analyses with Allocreadium apokryfi sp.n.

\begin{tabular}{|c|c|c|c|c|}
\hline Species & Host & Accession no. & Reference & Locality \\
\hline \multicolumn{5}{|l|}{ 28S rDNA } \\
\hline $\begin{array}{l}\text { Allocreadium neotenicum } \\
\text { Peters, } 1957\end{array}$ & $\begin{array}{l}\text { Hydroporus rufifrons } \\
\text { (beetle) }\end{array}$ & JX983204 & Bray et al. (2012) & $\begin{array}{l}\text { Lake District (South), Cumbria, United } \\
\text { Kingdom }\end{array}$ \\
\hline $\begin{array}{l}\text { Allocreadium mazoense } \\
\text { Beverly-Burton, } 1962\end{array}$ & Clarias gariepinus (fish) & DQ813450 & $\begin{array}{l}\text { Mwita and Nkwengulila } \\
(2010)\end{array}$ & Lake Victoria (South), Tanzania \\
\hline \multicolumn{5}{|l|}{$18 \mathrm{~S}$ rDNA } \\
\hline $\begin{array}{l}\text { Allocreadium gotoi (Hasega- } \\
\text { wa et Ozaki, 1926) }\end{array}$ & $\begin{array}{l}\text { Misgurnus anguillicaudatus } \\
\text { (fish) }\end{array}$ & ${ }^{s} \mathrm{LC} 215274$ & Shimazu (2017) & $\begin{array}{l}\text { Midori, Iiyama City, Nagano Prefecture, } \\
\text { Japan }\end{array}$ \\
\hline $\begin{array}{l}\text { Allocreadium handiai Pande, } \\
1937\end{array}$ & Mystus tengara (fish) & KX344072* & Chaudhary et al. (2016) & Fish market, Hastinapur and Meerut, India \\
\hline $\begin{array}{l}\text { Allocreadium hemibarbi } \\
\text { Roitman, } 1963\end{array}$ & Hemibarbus labeo (fish) & MK211220-3 & Vainutis (2020) & $\begin{array}{l}\text { Russia, Khankaisky district, Komissarovka } \\
\text { River }\end{array}$ \\
\hline $\begin{array}{l}\text { Allocreadium isoporum } \\
\text { (Looss, 1894) }\end{array}$ & Barbatula barbatula (fish) & MH143102 & Petkevičiūtè et al. (2018) & $\begin{array}{l}\text { River Il'd, upper Volga River basin, } \\
\text { Khankaisky district, Russia }\end{array}$ \\
\hline \multirow{3}{*}{$\begin{array}{l}\text { Allocreadium khankaiensis } \\
\text { Vainutis, } 2020\end{array}$} & Alburnus alburnus (fish) & GU462125-6 & Petkevičiūtè et al. (2010) & Lake Oster, Karelia, Russia \\
\hline & $\begin{array}{l}\text { Rhynchocypris oxycephalus } \\
\text { (fish) }\end{array}$ & MK211211-2 & Vainutis (2020) & $\begin{array}{l}\text { Poperechny spring, Komissarovka River } \\
\text { basin, Russia }\end{array}$ \\
\hline & & MK211213-9 & Vainutis (2020) & $\begin{array}{l}\text { Komissarovka River, Khankaisky district, } \\
\text { Russia }\end{array}$ \\
\hline \multirow[t]{2}{*}{$\begin{array}{l}\text { Allocreadium lobatum Wallin, } \\
1909\end{array}$} & $\begin{array}{l}\text { 1,Semotilus atromaculatus } \\
\text { (fish) }\end{array}$ & DQ029327 & $\begin{array}{l}\text { Platta and Choudhury } \\
\text { (2006) }\end{array}$ & Rose Isle Creek, Manitoba, Canada \\
\hline & Semotilus corporalis (fish) & EF032693 & Curran et al. (2006) & Moosehead Lake, Maine, USA \\
\hline \multirow[t]{5}{*}{$\begin{array}{l}\text { Allocreadium neotenicum } \\
\text { Peters, } 1957\end{array}$} & $\begin{array}{l}\text { Hydroporus rufifrons } \\
\text { (beetle) }\end{array}$ & JX977132 & Bray et al. (2012) & $\begin{array}{l}\text { Lake District (South), Cumbria, United } \\
\text { Kingdom }\end{array}$ \\
\hline & $\begin{array}{l}\text { Oreodytes sanmarkii } \\
\text { (beetle) }\end{array}$ & KY513132-3 & Soldánová et al. (2017) & Lake Takvatn, Troms County, Norway \\
\hline & $\begin{array}{l}\text { Pisidium casertanum } \\
\text { (bivalve) }\end{array}$ & MH143103 & Petkevičiūte et al. 2018) & River Burulcha, Crimea, Ukraine \\
\hline & & MH143104 & Petkevičiūtè et al. (2018) & Lake Takvatn, Norway \\
\hline & Pisidium sp. (bivalve) & MH143105 & Petkevičiūtè et al. (2018) & Lake Nordersjoen, Norway \\
\hline Allocreadium sp. & Phoxinus phoxinus (fish) & MK211209-10 & Vainutis (2020) & $\begin{array}{l}\text { River Nezhinka tributary, Razdolnaya River } \\
\text { basin, Russia }\end{array}$ \\
\hline Allocreadium sp. & Carassius carassius (fish) & MK258685-7 & Unpublished & Russia \\
\hline Allocreadium sp. & $\begin{array}{l}\text { Sphaerium corneum } \\
\text { (bivalve) }\end{array}$ & GU462121** & Petkevičiūtè et al. (2010) & River Belka, Dnieper River basin, Ukraine \\
\hline \multirow[t]{3}{*}{$\begin{array}{l}\text { Palaeorchis crassus (Wesen- } \\
\text { burg-Lund, 1934) }\end{array}$} & Pisidium amnicum (bivalve) & GU462117-20 & Petkevičiūtè et al. (2012) & River Žeimena, Lithuania \\
\hline & & JF261141-3 & Petkevičiūtè et al. (2012) & Siilaisenpuro River, Finland \\
\hline & & JF261144 & Petkevičiūtè et al. (2012) & River Ūla, Lithuania \\
\hline
\end{tabular}

to seminal receptacle. Vitelline duct joins posterior part of seminal receptacle, vitelline duct enlarged at posterior, running parallel to oviduct, connecting to vitellarium (Fig. 2C). Vitellarium occupies lateral fields, from level of ovary mostly extracaecal, crossing into intercaecal space from level of testes, then confluent in post-testicular region, 46-122 (87) from posterior extremity of body. Vitelline follicles densely clustered, irregular-shaped, 89-152 (121) long, 78-129 (94.6) wide. Seminal receptacle pear-shaped, in median line posterior to ovary, dilated posteriorly, curved anteriorly, 86256 (173) long, 79-160 (113) wide (Fig. 2A,C). Laurer's canal not clearly visible. Mehlis' gland surrounding ootype, along oviduct, oviduct opens into uterus (Fig. 2C).

Uterus coiled extensively, filling inter- and extracaecal space from mid-anterior testis to ventral sucker, partially overlapping ovary, ascending coils run dextrally to ventral sucker, opening into genital atrium, metraterm on both sides of distal part of uterus approaching genital atrium (Fig. 2B). Genital pore median, anterior to ventral sucker and caecal bifurcation (Figs. 2A, 3A). Eggs oval, operculate (Fig. 5B), shell yellow, often collapsed, 83-92 (87) long, 60-74 (66) wide. Excretory vesicle tubular, short, not reaching posterior testis (Fig. 2A). Excretory pore terminal (Figs. 3A, 4E).

Type host: Labeobarbus aeneus (Burchell), smallmouth yellowfish (Cypriniformes: Cyprinidae).

Type locality: Vaal River, downstream $( \pm 1.5 \mathrm{~km})$ of the Vaal Dam wall $\left(26.871111^{\circ} \mathrm{S}, 28.118611^{\circ} \mathrm{E}\right)$.

Site of infection: Anterior to middle intestine.

Infection parameters : prevalence 33\% (7 of 21 fish infected); intensity $1-15$ (mean 8.3 ); abundance 2.8 .

Specimens deposited: Holotype-ovigerous adult specimen deposited at the Iziko South African Museum, Cape Town, South Africa (SAMC-A092079); paratypes: three specimens deposited at the Iziko South African Museum, Cape Town, South Africa (SAMC-A092080-2); three specimens deposited at the Natural History Museum, London, UK (NHMUK 2020.12.16.1-3); and three specimens deposited at the Institute of Parasitology, Czech Academy of Sciences, České Budějovice, Czech Republic (IPCAS D-831).

Representative DNA sequences: All genetic material produced deposited to GenBank, five sequences for $28 \mathrm{~S}$ rDNA (MW907591-MW907595) and five sequences for 18S rDNA (MW907958-MW907962). 
A

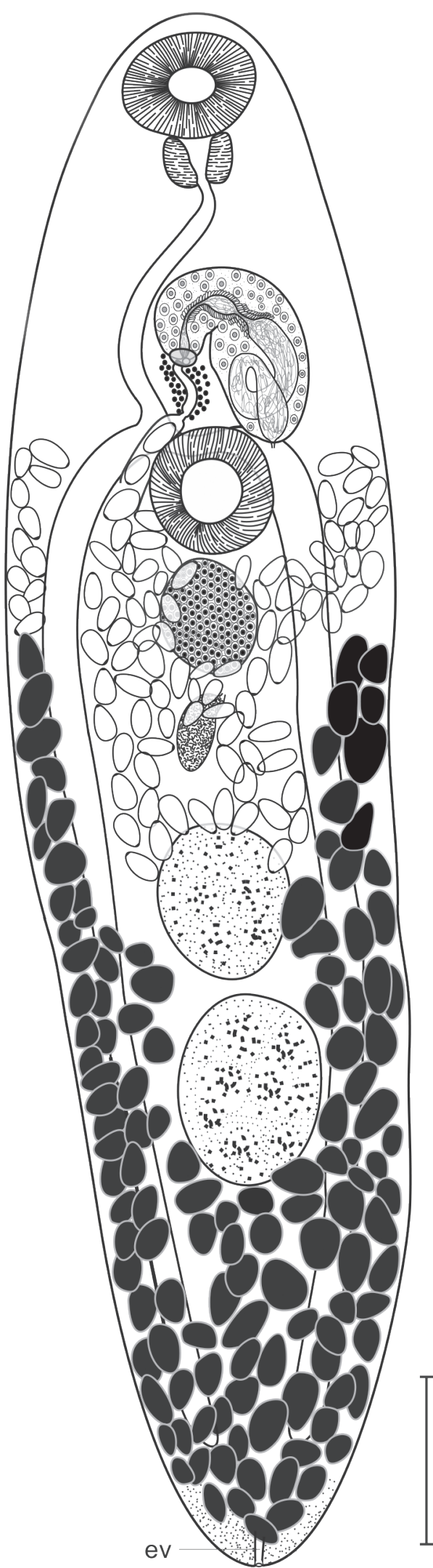

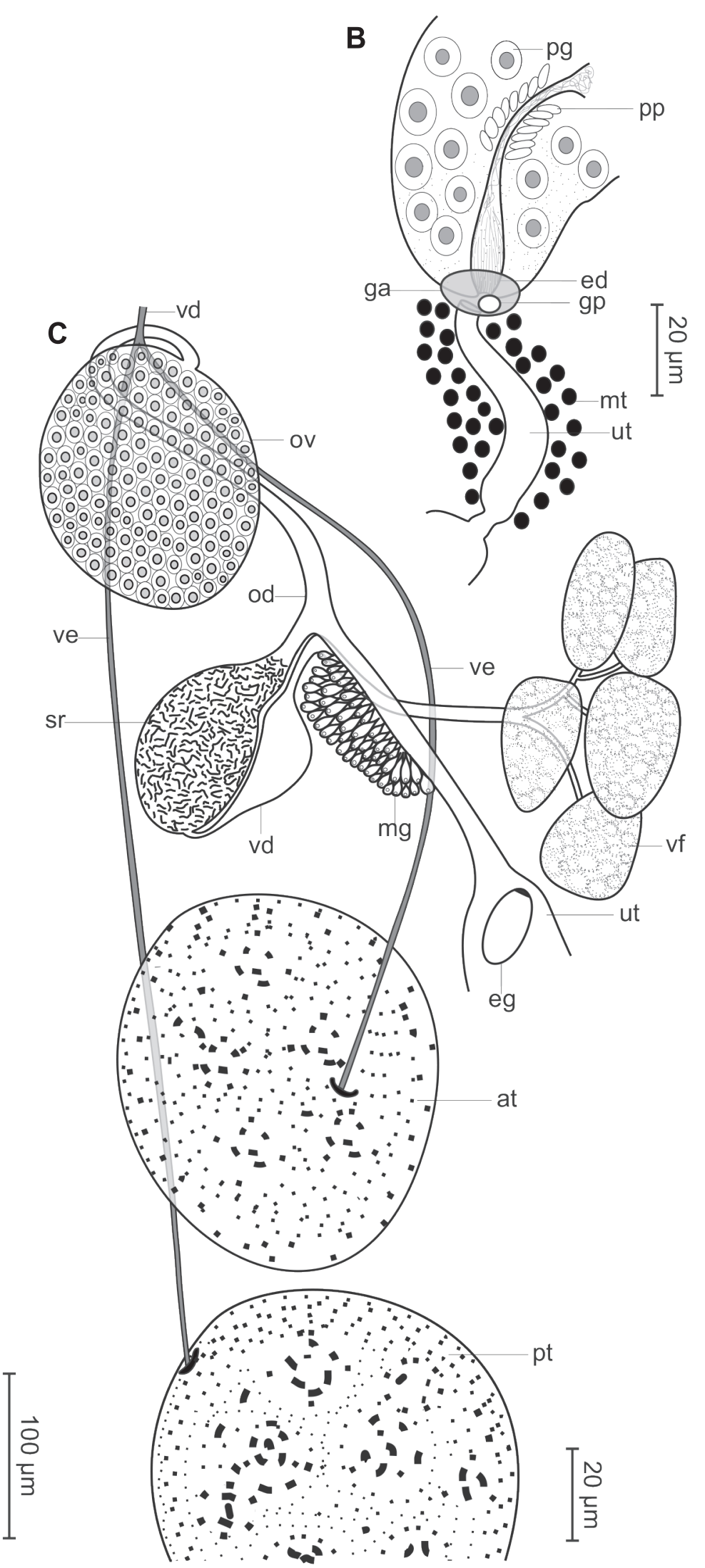

Fig. 2. Allocreadium apokryfi sp. n. from Labeobarbus aeneus (Burchell) in South Africa. A - ventral view of whole specimen; B termination of genitalia at genital pore; $\mathbf{C}$ - reproductive organs. Abbreviations: at - anterior testis; ed - ejaculatory duct; eg - egg; ev - excretory vesicle; ga - genital atrium; gp - genital pore; $\mathrm{mg}$ - Mehlis gland; mt - metraterm; od - oviduct; ov - ovary; pg - prostatic gland cell; pp - pars prostatica; $\mathrm{pt}$ - posterior testis; sr - seminal receptacle; ut - uterus; vd - vasa deferens; vd - vitelline duct; ve - vas efferentia; vf - vitelline follicle. 


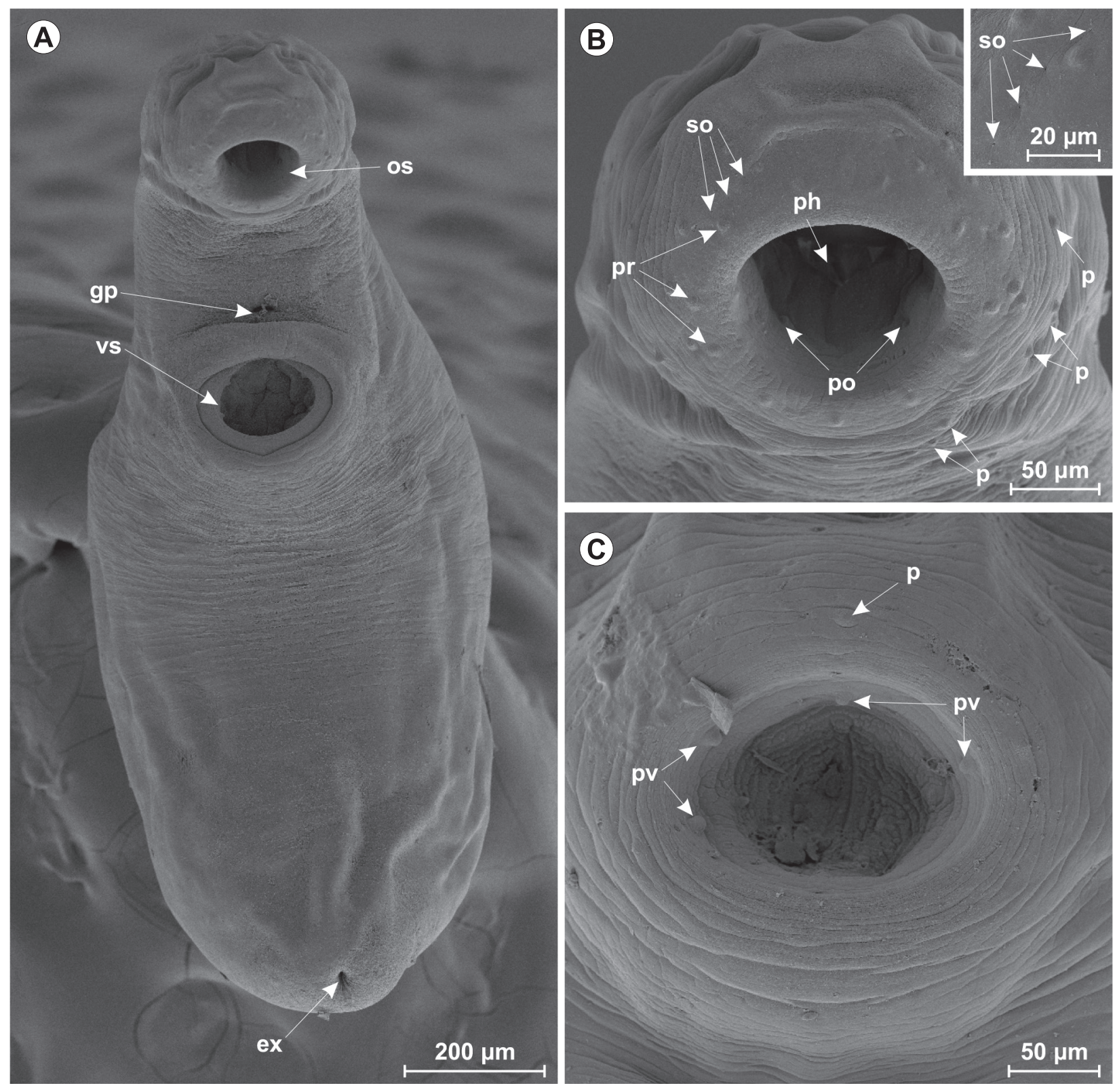

Fig. 3. Scanning electron micrographs of Allocreadium apokryfi sp. n. from Labeobarbus aeneus (Burchell) in South Africa. A - ventral view of whole specimen; B - oral sucker (insert showing possible sensory openings); C - ventral sucker. Abbreviations: ex - excretory pore; gp - genital pore; os - oral sucker; $\mathrm{p}$ - papillae; ph - pharynx; po - papillae in oral sucker; pr - papillae on rim of oral sucker; pv - papillae in ventral sucker; so - sensory openings; vs - ventral sucker.

Etymology: The species name is based on the Greek word

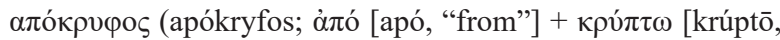
"I hide"]), referring to the cryptic nature of the species and that it has remained hidden in a well-studied river for so long.

\section{Remarks}

In having an oral sucker without muscular papillae, caeca extending to near the posterior extremity of the body, uterus not extending posteriorly beyond testes, long oesophagus, vitellarium mostly restricted to hindbody, and the ovary not restricted to the anterior third of the body (Caira and Bogéa 2005), specimens of the present study are assigned to the genus Allocreadium. Allocreadium spp. previously described from Africa $(\mathrm{n}=8)$ are all described based on adult specimens and are similar to Allocreadium apokryfi sp. $\mathrm{n}$. in that the ventral sucker is larger than the oral sucker (see Table 1), with the exception of Allocreadium indistinctum and $A$. aswanense for which the suckers are nearly equal.

Among African species of Allocreadium, A. apokry$f i$ sp. n. most closely resembles $A$. aswanense, with both species possessing a vitellarium that extends from the ovary level and the presence of an intertesticular space (El-Naffar et al. 1984). Nevertheless, $A$. apokryfi sp. n. differs from $A$. aswanense by having a bipartite internal seminal vesicle (vs. unipartite), a genital pore near the ventral sucker (vs. pharynx), an intestinal bifurcation at the ventral sucker level (vs. anterior to the ventral sucker), a larger ventral than the oral sucker (vs. suckers equal in size) and wider eggs. 

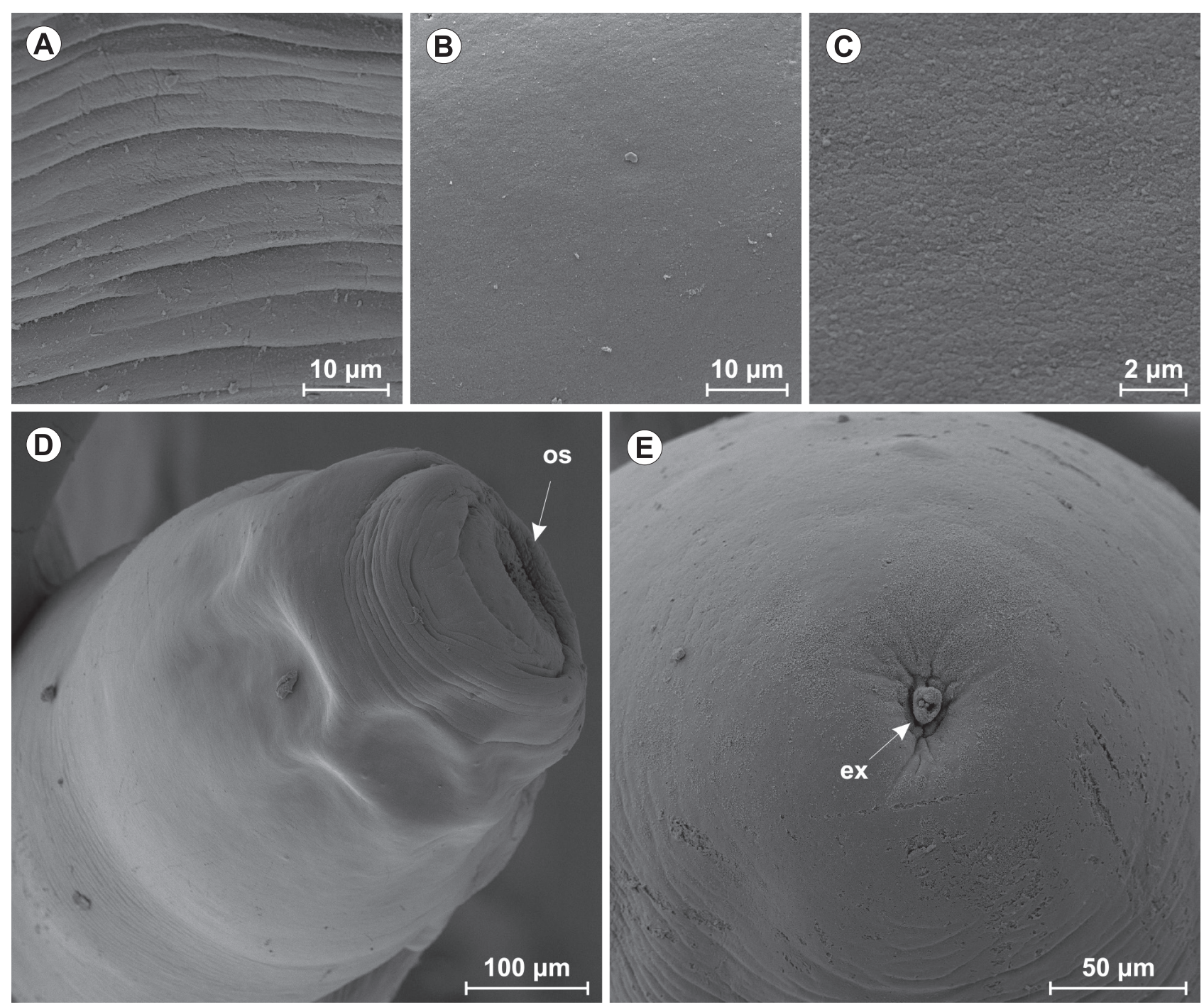

Fig. 4. Scanning electron micrographs of the tegument and posterior extremity of Allocreadium apokryfi sp. n. from Labeobarbus aeneus (Burchell) in South Africa. A - tegumental folds in the forebody; B - posterior ventral tegument; $\mathbf{C}$ - cobblestone-like structure of tegument; D - ventral view of the forebody; $\mathbf{E}$ - posterior extremity of the body. Abbreviations: ex - excretory pore; os - oral sucker.

The new species and $A$. aswanense further differ in the type host and locality with $A$. apokryfi sp. n. from $L$. aeneus in South Africa, whereas A. aswanense is from the Niger barb, Labeobarbus bynni (Forsskål), in Egypt. However, the congeneric nature of the hosts of $A$. apokryfisp. n. and A. aswanense may explain their similarity.

Allocreadium apokryfi sp. n. can be distinguished from the remainder of African species of Allocreadium by a dorsally bifurcating oesophagus at the level of the ventral sucker instead of anterior to the ventral sucker (Thomas 1957, Fischthal and Thomas 1972, Khalil and Thurston 1973, Saoud et al. 1974, El-Naffar et al. 1984, El-Naffar 1986). Additionally, both $A$. sudanense and A. indistinctum possess overlapped testes (Baer 1959, Saoud et al. 1974), whereas Allocreadium bynni has oblique testes (El-Naffar 1986), rather than the presence of an intertesticular space in the new species. Allocreadium voltanum is the only African species having lobed testes (Thomas 1957), whereas they are rounded and smooth in the new species. In both Allocreadium ghanense and Allocreadium engraulicyp- ridis, the vitellarium extends deeply into the forebody to the pharynx level, whereas it extends to the ovary level in $A$. apokryfi sp.n. Furthermore, A. ghanense possesses a prepharynx and eye spot pigment granules at the pharynx level (Fischthal and Thomas 1972) whereas they are absent in the new species. The genital pore of $A$. engraulicypridis opens posterior to the caecal bifurcation rather than more anteriorly as seen in the new species. The genital pore position of Allocreadium mazoense is similar to that of $A$. apokryfi sp.n. (Beverley-Burton 1962).

The new species differs from the majority of European, Asian and American species of Allocreadium in that the vitellarium extends to the ovary level and not deeply into the forebody towards the pharynx, near the caecal bifurcation or ventral sucker (Odhner 1901, Wallin 1909, Mueller and Van Cleave 1932, Rankin 1937, Peters 1957, Odening 1959, Akhmerov 1960, Rai 1962, Rees 1968, Kakaji 1969, Koval 1972, Fischthal and Nasir 1974, Shimazu et al. 2000, Flores et al. 2004, Shimazu 2016, Vainutis 2020). The new species also differs from other Asian and Ameri- 

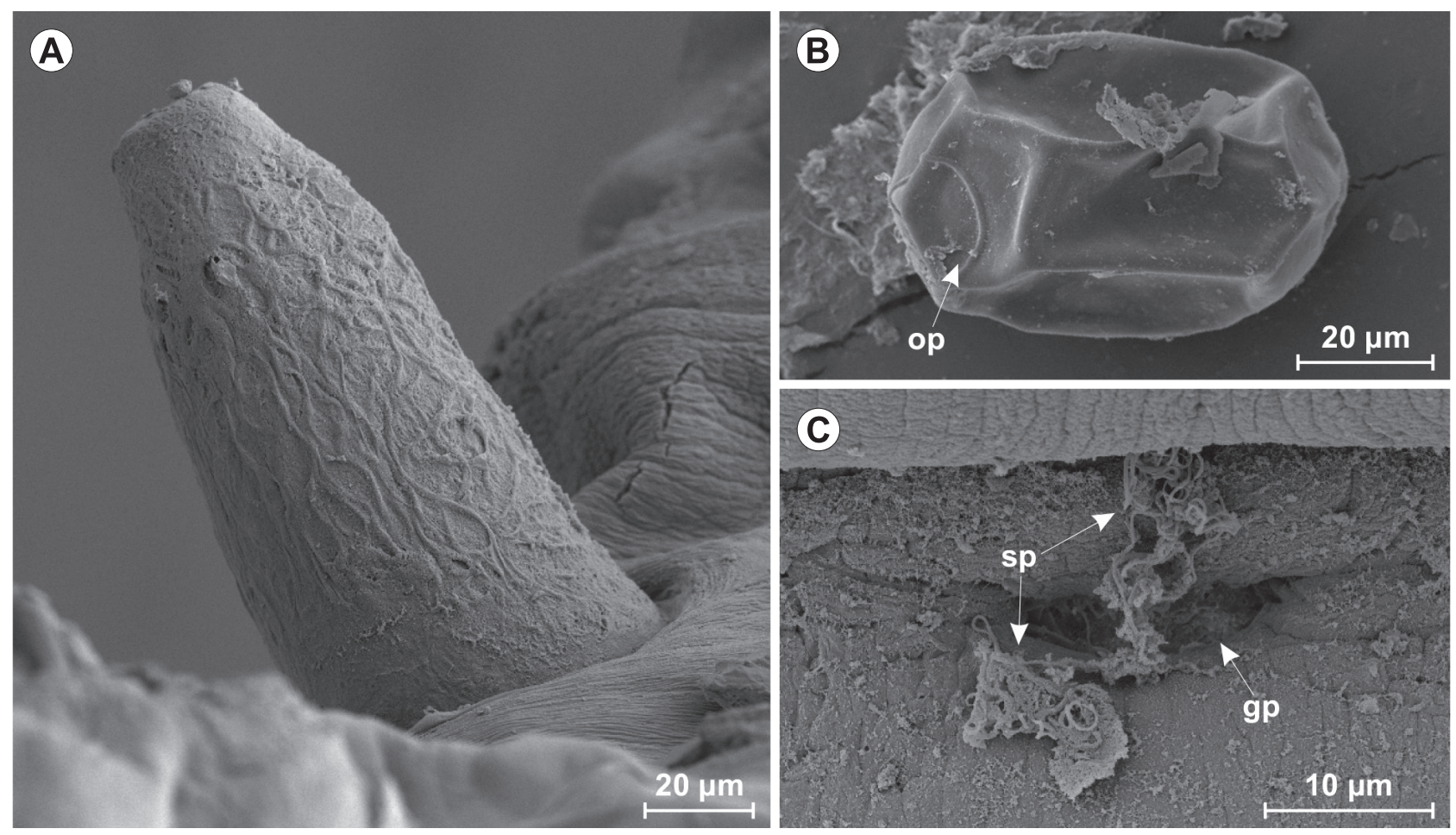

Fig. 5. Scanning electron micrographs of reproductive structures of Allocreadium apokryfi sp. n. from Labeobarbus aeneus (Burchell) in South Africa. A - protruding cirrus; B - egg; C - genital pore with possible sperm. Abbreviations: go - genital pore; op - operculum; sp - sperm.

can species of Allocreadium in that the oesophagus bifurcates at the level of the ventral sucker instead of anterior to the ventral sucker (Pande 1937, Gupta 1956, Rai 1962, Agrawal 1964), and that the testes are round and smooth, not lobed (Wallin 1909, Fischthal and Nasir 1974).

\section{Molecular data analyses}

Sequence data for both $18 \mathrm{~S}$ and $28 \mathrm{~S}$ rDNA fragments were successfully obtained from all specimens of $A$. apokryfi sp.n. analysed $(\mathrm{n}=5)$. Only a single haplotype was observed for each marker from all individuals, indicating no intraspecific variation in these samples for the designated rDNA fragments. BLAST of the obtained $18 \mathrm{~S}$ rDNA sequence ( $904 \mathrm{bp}$ ) confirmed the similarity of the specimens to species of Allocreadium. Generated $18 \mathrm{~S}$ rDNA was aligned to two $18 \mathrm{~S}$ sequences for species of Allocreadium from GenBank, producing an alignment of seven sequences consisting of 905 bp, with 849 conserved, 55 variable, and 1 parsimony informative sites. Based on p-distances of $18 \mathrm{~S}$ rDNA, $A$. apokryfi sp.n. is $1.2 \%$ different from Allocreadium neotenicum Peters, 1957 (JX983204), while it was $9.1 \%$ from A. mazoense (DQ813450).

Using all other rDNA sequence data on species of Allocreadium available, $4128 \mathrm{~S}$ rDNA sequences for the genus were aligned to that of $A$. apokryfi sp. n. (haplotype of 1,255 $\mathrm{bp})$. The produced alignment contained 46 sequences and consisted of 1,258 bp, with 1,102 conserved, 156 variable, and 149 parsimony informative sites. Evolutionary divergence between sequences based on $p$-distances is presented in Table 3. Allocreadium apokryfi sp.n. was most closely related to Allocreadium hemibarbi Roitman, 1963 (4.7\%,
MK211220-MK211223), whereas Allocreadium lobatum Wallin, 1909 was the most distant (6.5\%, DQ029327). Using only sequence data for specimens identified to species level, intraspecific distances of $0-0.3 \%$ were calculated with interspecific distances of $0.3-6.5 \%$.

Based on the BI topology (Fig. 6) based on analysis of the 28S rDNA alignment, sequences for $A$. apokryfi sp.n. form a distinct clade. This clade is well supported by both BI and ML methods, with branching within the clade being negligible. Allocreadium apokryfi sp. n. groups sister to most other species of Allocreadium, except for unidentified specimens from Russia (MK258685-7; unpublished), which are basal to the other species of the genus. All taxa included form well supported ( $>90 \%$ ) clades supporting their distinctness, except for A. lobatum and A. neotenic$u m$, in which only BI support is strong enough for the formation of a clade of the first species and ML support is low ( $>65 \%$ ). However, intraspecific nodes for the genus are well supported only by BI analyses, with most ML nodes having low support. Based on the large distances observed between both the $18 \mathrm{~S}$ and $28 \mathrm{~S}$ rDNA haplotypes generated in the current study and published sequence data, and the formation of a distinct clade in Fig. 6, A. apokryfi sp.n. represents a species not genetically characterised before.

\section{Updated key to the species of Allocreadium from African freshwater fishes}

The key is based on the rearrangement of those by El-Naffar et al. (1984) and El-Naffar (1986), using the following additional features: pharynx length, level of the 


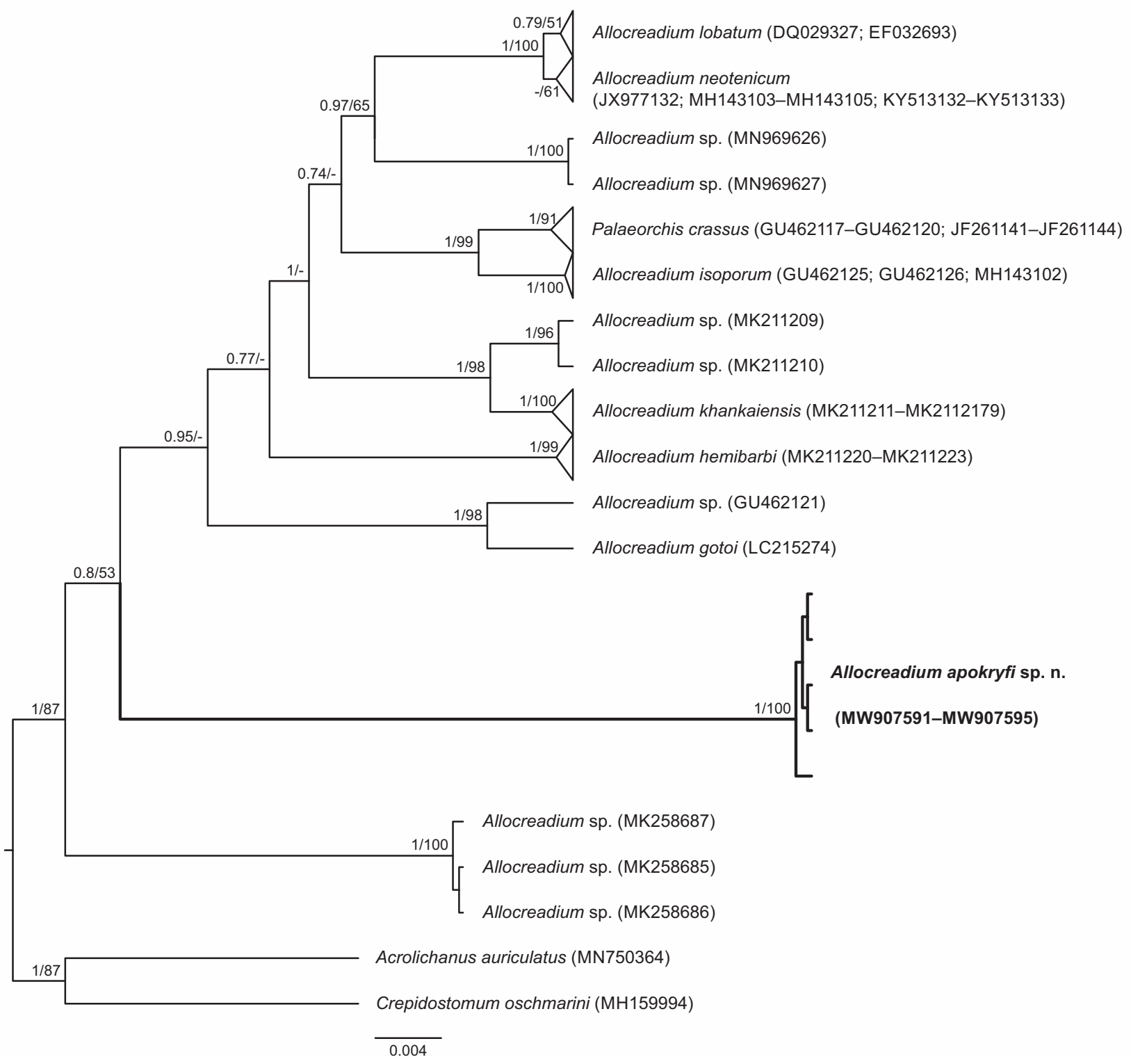

Fig. 6. Topology based on $28 \mathrm{~S}$ rDNA using Bayesian Inference (BI) approaches indicating the evolutionary history of Allocreadium apokryfi sp. n. in relation to other species of Allocreadium and Palaeorchis crassus (Wesenburg-Lund, 1934), with Acrolichanus auriculatus (Wedl, 1858) and Crepidostomum oschmarini Zhokhov et Pugacheva, 1998 used as outgroup. Support for BI (10 million MCMC), and maximum likelihood (ML, 1000 bootstrap replicates) indicated at nodes (BI/ML), nodes with less than $50 \%$ support indicated with "-".

intestinal bifurcation, extent of tegumental spines, and position of the genital pore and cirrus-sac.

1a Testes lobed A. voltanum

$1 \mathrm{~b}$ Testes spherical or oval with smooth outline ....2

2a Vitellarium extending to the pharyngeal level ... ....3

$2 \mathrm{~b}$ Vitellarium not extending anteriorly beyond the ventral sucker.

3a Cirrus-sac elongate enclosing a bipartite internal seminal vesicle ............................. ghanense 3b Cirrus-sac roughly oval enclosing a unipartite internal seminal vesicle ...................... A. engraulicypridis 4a Tegumental spines present anteriorly ...... A. mazoense 4b Tegumental spines absent ... 5 5a Vitellarium extending only to the anterior testis, the eggs longer than $95 \mu \mathrm{m}$ A. indistinctum $5 \mathrm{~b}$ Vitellarium extending to the ovary; eggs shorter than $95 \mu \mathrm{m}$ .. 6 6 6 Oesophagus short; intertesticular space absent ....... 7 $6 \mathrm{~b}$ Oesophagus long; two testes separated by intertesticular space ....

7a Testes symmetrical; ovary immediately posterior to the anterior testis A. sudanense $7 \mathrm{~b}$ Testes oblique; ovary separated from the anterior testis by a space A. bynni 8a Intestinal bifurcation anterior to the ventral sucker; genital pore near the pharynx A. aswanense $8 \mathrm{~b}$ Intestinal bifurcation at level of the ventral sucker; genital pore near the ventral sucker .... Allocreadium apokryfi sp. n. 


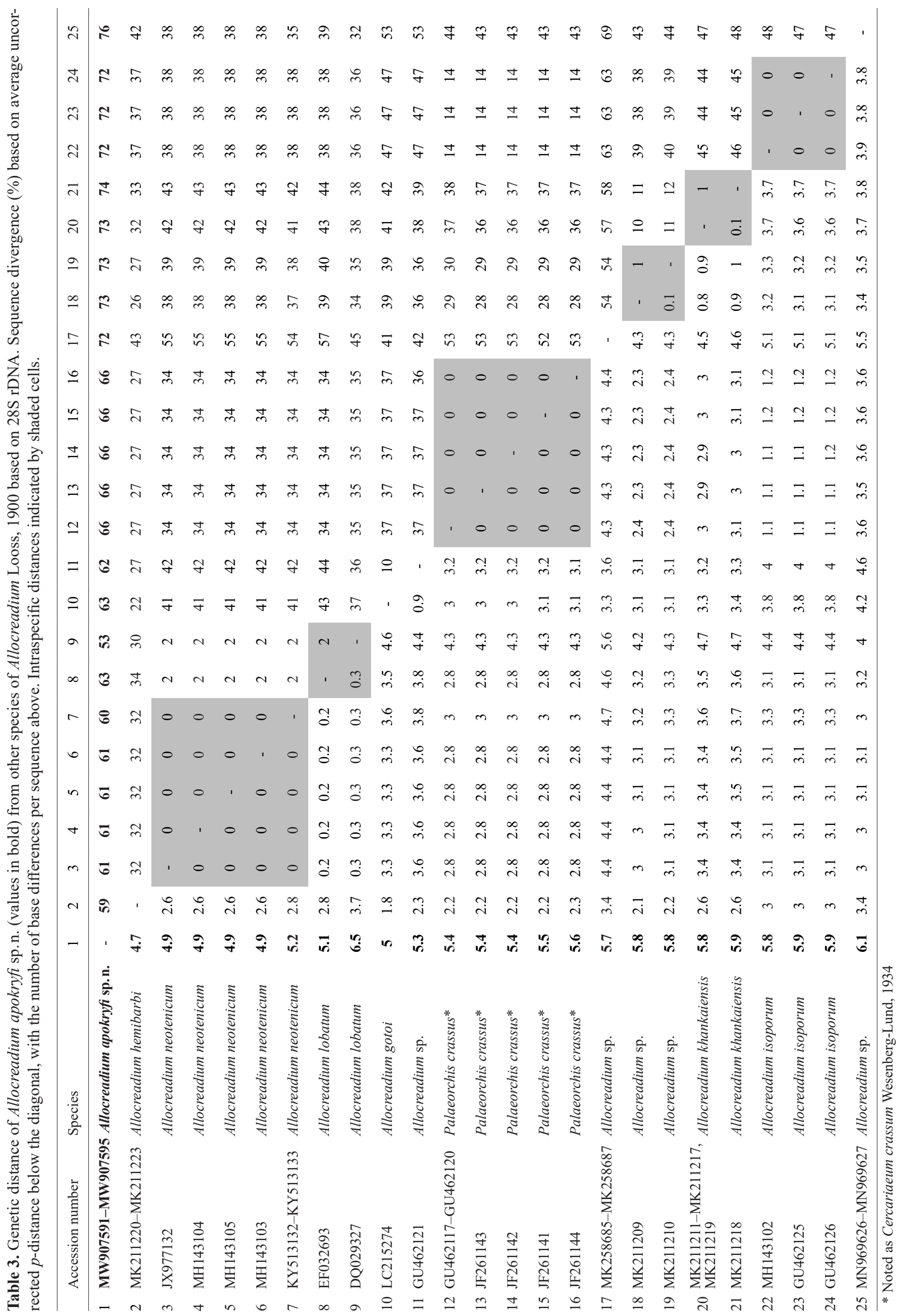




\section{DISCUSSION}

\section{Taxonomy}

The present study increases the number of species of Allocreadium recorded from Africa to nine. Globally, more than 100 species of this genus are accepted as biologically distinct (WoRMS 2020). The first key to African species of Allocreadium was presented by Saoud et al. (1974) and included five species distinguished by the testis shape, egg size and the structure and extent of the vitellarium. El-Naffar et al. (1984) and El-Naffar (1986) updated the key to include eight nominal species based on the shape and position of the testes, extent of the vitellarium and the oesophagus length. By reworking these keys and adding the information on Allocreadium apokryfi sp. n., a new key was produced based on the length of the pharynx, arrangement of tegumental spines and the position of the genital atrium and cirrus-sac. However, a revision of all known African species, including updated morphology and molecular characterisation, may alter the key.

Surface ultrastructure of the new species studied using SEM differed from what has previously been observed for species of Allocreadium. Currently, only one other species of the genus, Allocreadium danjiangense Gao, Wang, Xi, Yao et Nie, 2008 has been studied using SEM (Gao et al. 2008). Although the tegument of both A. apokryfi sp.n. and $A$. danjiangense is smooth, with tegumental striations present, the tegumental striations dissipate posteriorly in A. apokryfi sp.n., whereas they become denser and shallower in the posterior part of the body of $A$. danjiangense. Additionally, the protuberant rugae on the dorsal surface, dorsal tubercles and muscular grids around the oral and ventral sucker edges were not observed in A. apokryfi sp.n. Tongue-like tubercles were seen in the ventral sucker of the new species but did not occur in a groove. The tortoise shell-like tegumental structure between the oral sucker of A. danjiangense was similar to the cobblestone-like tegumental nature of $A$. apokryfi sp.n. Unfortunately, Gao et al. (2008) did not produce any molecular data and thus the differences in surface topology cannot be related to phylogenetic relationships of both taxa. However, the surface ultrastructure of these two allocreadiids is far more similar to one another than to other allocreadiid species studied using SEM, such as Crepidostomum farionis (Müller, 1780), Crepidostomum metoecus (Braun, 1900) and Crepidostomum oschmarini in that no tegumental bosses, ciliated papillae or lobes are present (Moravec 2002, Petkevičiūtè et al. 2018).

It would be an interesting future endeavour to determine if the papillae of species of Allocreadium can also be separated into different types as observed by Žd'árská and Nebesářová (2004) in C. metoecus using transmission electron microscopy, although ciliated receptors were absent in $A$. apokryfi sp.n. Interestingly, structures similar to the minute sensory receptors (Moravec 2002) or non-papillate sensory endings (Petkevičiūtè et al. 2018) observed on the dorsal part of the oral sucker in Crepidostomum spp. appear to be present in $A$. apokryfi sp. n. and have been noted as possible sensory openings. However, their composition and function need further investigation, including TEM observation. The number and arrangement of the tegumental papillae on the ventral tegument around the oral and ventral suckers of $A$. apokryfi sp.n. will also need further investigation as this was not consistent among the specimens studied here.

The observation of the protruded cirrus of A. apokry$f i$ sp.n. is the first of its kind for this genus. The cirrus appears to be far shorter and stouter than that of other allocreadiids like $C$. oschmarini. The elevation of the genital pore around the cirrus is similar to that seen by Petkevičiūte et al. (2018) for C. oschmarini, but the cirrus surface in A. apokryfi sp.n. is not smooth; it is covered with lace- or sponge-like structures. Whether this feature is characteristic of all species of Allocreadium or only the new species will have to be confirmed. The observation of possible sperm at the genital pore opening is also noteworthy and may be the result of interrupted copulation. The further study of these structures may be interesting.

Both 18S and 28S rDNA fragments assessed for the new species support that this species is clearly distinct from all other taxa for which sequence data are available. The distance between the new species for both regions amplified (1.2-9.1\% for $18 \mathrm{~S}$ and $4.7-6.5 \%$ for $28 \mathrm{~S}$ ) is large and in the case of $28 \mathrm{~S}$ rDNA, far higher than the observed intraspecific range of $0-0.3 \%$. It is also possible that the overlap resulting from the high intraspecific distances observed between the two sequences for A. lobatum $(0.3 \%)$ and the low interspecific distances between A. lobatum and Allocreadium neotenicum $(0.2-0.3 \%)$ may indicate that these species are synonyms, as has been suggested in earlier work (Bray et al. 2012). This would mean that the intraand interspecific ranges for $28 \mathrm{~S}$ rDNA of Allocreadium are actually $0-0.3 \%$ and $0.8-6.5 \%$, respectively. Additionally, A. apokryfi sp.n. forms a well-supported, distinct clade. However, sequence data are currently only available for seven identified species of Allocreadium, excluding another four possibly distinct taxa which are not identified, and Palaeorchis crassus which falls within the ingroup. Even if all the unidentified species are considered distinct and $P$. crassus is considered a congener, only 12 taxa have representative molecular data, which is strikingly less than the 107 suggested Allocreadium spp. on WoRMS (2020).

The low number of taxa for which genetic information is available, the high number of unidentified species for which data are available, the inclusion of $P$. crassus in the Allocreadium ingroup, and the low bootstrap support observed at deeper nodes of the produced topology, all indicate that there is still much to be elucidated regarding the phylogeny of this genus. However, the basal placement of the unpublished sequences for an unidentified Allocreadium sp. collected in Russia (MK258685-MK258687), with those of $A$. apokryfi sp.n. in the ingroup, may support the speculated origin of the group in the south of the Far East (Manter 1963, Vainutis 2020). Nevertheless, the need for additional molecular study of this group is exemplified by the exclusion of sequence KX344072 (Chaudhary et al. 2016) in the current work. It was designated as Allocreadium handiai Pande, 1937 but does not relate to oth- 
er 28S rDNA for Allocreadium spp. and instead appears to be more closely related to Haplorchoides Chen, 1949 (Heterophyidae) when using BLAST. Similarly, sequences GU462111 and GU462116 are designated as Allocreadium isoporum (Looss, 1894) in their respective publication (Petkevičiūtè et al. 2010), but are identified as Bunodera luciopercae (Müller, 1776) in GenBank, which is supported by BLAST analyses. This accentuates the need for a more in-depth investigation into the molecular identity of this genus. Other markers (COI mtDNA and ITS rDNA) have also been used for the study of allocreadiids, but all taxa for which data are available have been included in either the $18 \mathrm{~S}$ or $28 \mathrm{~S}$ rDNA analyses.

\section{Definitive hosts and specificity}

The definitive hosts of these trematodes appear to be mostly species of Actinopterygii (ray-finned fishes), with various groups and families serving as hosts to adults of species of the genus. In Africa, definitive hosts for species of Allocreadium have been recorded from four orders: Characiformes $(\mathrm{n}=1)$, Perciformes $(\mathrm{n}=1)$, Siluriformes $(\mathrm{n}=3)$, and Cypriniformes $(\mathrm{n}=7)$ (Thomas 1957, Baer 1959, Beverley-Burton 1962, Fischthal and Thomas 1972, Khalil and Thurston 1973, Saoud et al. 1974, Moravec 1977, Jones 1982, Mashego 1982, El-Naffar et al. 1984, El-Naffar 1986, Mbahinzireki 1987, Mwita and Nkwengulila 2010, Mwita 2014). However, adult A. neotenicum has also been collected from beetles in Europe, Hydroporus rufifrons (Müller) by Bray et al. (2012) and Oreodytes sanmarkii (Sahlberg) by Soldánová et al. (2017), indicating other groups as possible hosts of progenetic stages.

Allocreadium mazoense is one of the few Allocreadium spp., and the only species from Africa, which has been recorded from more than one host species (six fish species from three families). Although A. mazoense was described from Clarias gariepinus (Burchell), it has been speculated that the Cyprinidae are the true hosts for this species as most recorded hosts are of this family (Mashego 1982). This is supported by the fact that sampling efforts in which the parasites were recorded from cyprinids did not reveal infections in $C$. gariepinus even when the fish was present (Mashego 1982). The spread and identity of $A$. mazoense in Africa may also need to be revised as some of the records may have been misidentified. For example, Jones (1982) examined A. mazoense from Enteromius camptacanthus (Bleeker) but did not observe anterior tegumental spines. These spines appear to be a key feature of the species, and thus the trematode studied by Jones (1982) may have represented a distinct species. Additionally, Jones (1982) analysed the type material of $A$. mazoense and could not detect the spines noted in the original description. This could indicate a need to use SEM and molecular approaches to solve this riddle.

In contrast to the loose specificity of $A$. mazoense, three species of Allocreadium from Africa, A. bynni, A. sudanense and $A$. aswanense, were described from the same host species (Labeobarbus bynni) within the same river system. The identity and host allocation of these three species also require revision. In the description of $A$. sudanense by Saoud et al. (1974), and in later papers (El-Naffar et al. 1984, El-Naffar 1986), the host is noted as L. bynni, but in El-Naffar (1986) it is also given as Bagrus bajad (Forsskål), a catfish referred to as a cyprinid. Additionally, the description of A. bynni is accredited to El-Naffar (1970) in El-Naffar et al. (1984) but is then described in El-Naffar (1986) as a new taxon. This may be why A. bynni is not mentioned again in other papers, with later publications and online databases not listing the taxon (Khalil and Polling 1997, Kudlai et al. 2018, WoRMS 2020). Again, this would be a good opportunity to use modern techniques to determine the distinctness or synonymy of these taxa. Other species of Allocreadium in Africa, like Allocreadium voltanum, appear to fit the more general host specificity for members of Allocreadium, displaying strict host specificity (Thomas 1957). Thus, the host specificity of Allocreadium in Africa may not be as highly variable as reported.

\section{Intermediate hosts in Africa}

The intermediate hosts of species of Allocreadium in Africa are nearly unknown, with only Mbahinzireki (1987) broaching the topic. The author collected A. mazoense from the cichlid Haplochromis teegelaari Greenwood et Barel in Lake Victoria, noting that the host is molluscivorous. Using the feeding and ecology of the host, he inferred the possible life cycle of the trematode. He hinted at a level of host specificity in the system as a second congeneric molluscivore, Haplochromis ptistes Greenwood et Barel was not infected. He attributes this to either the level of adaptation of the parasite to the host, or the depth at which the two cichlid species occur, the latter of which may relate to the depth at which infective stages would be encountered. The first of these hypotheses seems unlikely due to the loose host specificity of $A$. mazoense as discussed, meaning that the second scenario is more likely. Mbahinzireki (1987) noted that Sphaerium sp. has been recorded as intermediate host of Allocreadium spp. previously, and thus the Mwanza Gulf clam (Sphaerium sp.) may be the local vector for A. mazoense. Unfortunately, the bivalve mollusc diversity and distribution in the Vaal River system are not well known. According to Appleton and Miranda (2015), species of three genera of the Sphaeriidae occur in southern Africa, of which only species of Pisidium Pfeiffer appear to occur in the central region of South Africa where the Vaal River system is situated. However, the identification and distribution of the eight species of Pisidium and their possible presence in the Vaal River system have not been well studied. Only Pisidium langleyanum Melvill et Ponsonby is noted in the reaches of the Vaal River system (De Kock and Wolmarans 2008) and thus may be the prime suspect as an intermediate host for $A$. apokryfi sp. n. The definitive host, Labeobarbus aeneus, is not exclusively molluscivorous, but rather broadly omnivorous (Skelton 2001). However, Skelton (2001) does make specific mention of bivalve molluscs forming a large part of the diet of L. aeneus, further supporting that they may be the source of the infection. 


\section{Ecology}

The parasite fauna of fish in the Vaal River system has been well studied for several decades. Especially the intestinal helminths of L. aeneus have been observed for several years from many sites in the system, with no record of trematodes having ever been detected (Bertasso and Avenant-Oldewage 2005). Therefore, the unexpected observation of a new trematode species in L. aeneus in the Vaal River is surprising. Three possibilities have been considered in this regard. The first is that the trematodes were introduced into the system with an invasive intermediate or definitive host, but based on our morphometric and molecular data, it would appear that the species does not match an existing taxon from Africa or the rest of the world. Additionally, no known allocreadiid has been recorded as invasive in southern Africa (Smit et al. 2017), nor from the fish or mollusc species which have been introduced to the area. The second scenario is that the range of a native, innominate species recently changed due to environmental or anthropogenic activities, but without accurate temporal and spatial data, along with the lack of knowledge on the distribution of molluscs in southern Africa, this is difficult to discuss at this time. The last scenario is that this species is native to the host and locality, but has not been detected before for some reason. Possible reasons may be a very short-lived period in the fish host and that the detection of species of Allocreadium is rare, which is supported by the findings of Mbahinzireki (1987), or that the range of the species has been limited to this single locality due to intermediate host populations, ecological factors, or even extinction in other regions. At present, we are unable to decide which of these scenarios are the most likely, but it could be a topic for future investigations to unravel the life cycle of the new species in order to elucidate its origin and transmission.

Acknowledgements. The authors appreciate funding from the University of Johannesburg Faculty and Central Research Committee (AA-O) and the University of Johannesburg Global Excellence and Stature Postdoctoral Fellowship program (QMDS). The National Research Foundation of South Africa is also thanked for its financial support to AA-O grant 115343 and a Postdoctoral Fellowship to BMG grant 120683. The Spectrum Analytical Facility at the University of Johannesburg is thanked for providing infrastructure for acquiring scanning electron micrographs. The authors would also like to express their sincere appreciation to the owners of the property at which collections for the current study took place, Bryan and Julia Webster, for their hospitality.

\section{REFERENCES}

Agrawal V. 1964: On some new trematodes from freshwater fishes of Lucknow. Ind. J. Helminthol. 16: 82-99.

Aknmerov A.H. 1960: [New trematode species from the River Amur.] Helminthologia 2: 286-294. (In Russian.)

Altschul S.F., Gish W., Miller W., Myers E.W., Lipman D.J. 1990: Basic local alignment search tool. J. Mol. Biol. 215: 403-410.

Appleton C., Miranda N. 2015: Molluscs. In: C. Griffiths, J. Day and M. Picker (Eds.), Freshwater Life. A Field Guide to the Plants and Animals of Southern Africa. Penguin Random House South Africa, Cape Town, pp. 124-137.

Avenant-Oldewage A., Le Roux L.E., Mashego S.N., Jansen VAN VuUren B. 2014: Paradiplozoon ichthyoxanthon n. sp. (Monogenea: Diplozoidae) from Labeobarbus aeneus (Cyprinidae) in the Vaal River, South Africa. J. Helminthol. 88: 166-172.

BAER J.G. 1959: Helminthes parasites. In: J.G. Baer and W. Gerber (Eds.), Exploration des Parcs Nationaux du Congo Bèlge. Imprimerie Hayez, Brussels, 163 pp.

Bertasso A., Avenant-Oldewage A. 2005: Aspects of the ecology of the Asian tapeworm, Bothriocephalus acheilognathi Yamaguti, 1934 in yellowfish in the Vaal Dam, South Africa. Onderstepoort J. Vet. Res. 72: 207-217.

Beverley-Burton M. 1962: Some trematodes from Clarias spp. in the Rhodesias, including Allocreadium mazoensis n. sp. and Eumasenia bangweulensis n. sp., and comments on the species of genus Orientocreadium Tubangui, 1931. Proc. Helminthol. Soc. Wash. 29: 103-115.

Bouckaert R., Heled J., Kühnert D., Vaughan T., Wu C.H., Xie D., Suchard M.A., Rambaut, A., Drummond A.J. 2014: BEAST 2: A software platform for Bayesian evolutionary analysis. PLoS Comput. Biol. 10: e1003537.

Bray R.A., Foster G.N., Waeschenbach A., Littlewood D.T.J. 2012: The discovery of progenetic Allocreadium neotenicum Peters, 1957 (Digenea: Allocreadiidae) in water beetles (Coleoptera: Dytiscidae) in Great Britain. Zootaxa 3577: 58-70.
Bush A.O., Lafferty K.D., Lotz J.M., Shostak A.W. 1997: Parasitology meets ecology on its own terms: Margolis et al. revisited. J. Parasitol. 83: 575-583.

CAIra J.N., Bogéa T. 2005: Family Allocreadiidae Looss, 1902. In: A. Jones, R.A. Bray and D.I. Gibson (Eds.), Keys to the Trematoda, Volume 2. CABI, Wallingford and the Natural History Museum, London, pp. 416-436.

Campos A., Cummings M.P., Reyes J.L., Laclette J.P. 1998: Phylogenetic relationships of Platyhelminthes based on $18 \mathrm{~S}$ ribosomal gene sequences. Mol. Phylogenet. Evol. 10: 1-10.

Chaudhary A., Mukut S., Singh H.S. 2016: Molecular characterization of three species belongs to the Allocreadioidea, Hemiuroidea and Plagiorchioidea (Platyhelminthes: Trematoda) infecting freshwater fishes in India. Helminthologia 53: 378-384.

Curran S.S., TKach V.V., Overstreet R.M. 2006: A review of Polylekithum Arnold, 1934 and its familial affinities using morphological and molecular data, with description of Polylekithum catahoulensis sp. nov. Acta Parasitol. 51: 238-248.

Dos Santos Q.M., Jansen van Vuuren B., Avenant-OldeWAGE A. 2015: Paradiplozoon vaalense n. sp. (Monogenea: Diplozoidae) from the gills of moggel, Labeo umbratus (Smith, 1841), in the Vaal River System, South Africa. J. Helminthol. 89: 58-67.

El-Naffar M.K. 1970: Studies on the parasites of Nile fishes in Assiut Province of Egypt. PhD Thesis, Assiut University, Assiut.

EL-NAFFAR M.K. 1986: Allocreadium sp. n., a trematode parasite from a freshwater fish at Assiut province, A.R. Egypt. Assiut Vet. Med. J. 15: 39-45.

El-Naffar M.K., Saoud M.F., Hassan I.M. 1984: Allocreadium aswanensis sp. n., a trematode parasite from a freshwater fish (Barbus bynni) from Lake Nasser at Aswan, A.R. Egypt. Assiut Vet. Med. J. 12: 61-65.

Fischthal J.H., Nasir P. 1974: Some digenetic trematodes from freshwater and marine fishes of Venezuela. Norw. J. Zool. 22: 71-80.

Fischthal J.H., Thomas J.D. 1972: Digenetic trematodes of fish from the Volta River drainage system in Ghana prior to the con- 
struction of the Volta Dam at Akosombo in May 1964. J. Helminthol. 46: 91-106.

Flores V.R., Brugni N., Ostrowski De NúÑez M. 2004: Allocreadium pichi n. sp. (Trematoda: Allocreadiidae) in Galaxias maculatus (Osteichthyes: Galaxiidae) from Lake Moreno in Patagonia (Argentina). Syst. Parasitol. 58: 217-221.

Gao D., Wang G.T., Xi B.W., Yao W.Y., Nie P. 2008: A new species of Allocreadium (Trematoda: Allocreadiidae) from freshwater fishes in the Danjiangkou Reservoir in China. J. Parasitol. 94: 176-180.

Gupta S.P. 1956: Two new trematodes of the family Allocreadiidae from the freshwater fishes of U.P. Ind. J. Helminthol. 8: 100-106.

Jones A. 1982: Some digeneans from African freshwater fishes, including Halipegus ctenopomi n. sp. (Vermes). Rev. Zool. Afric. 96: $1-10$

KaKaji V.L. 1969: Studies on helminth parasites of Indian fishes. Part. III. On some species of the genus Allocreadium Looss, 1900. Ann. Parasitol. (Paris) 44: 131-146.

Katoh K., Misawa K., Kuma K., Miyata T. 2002: MAFFT: a novel method for rapid multiple sequence alignment based on fast Fourier transform. Nucl. Acids Res. 30: 3059-3066.

Katoh K., Standley D.M. 2013: MAFFT multiple sequence alignment software version 7: improvements in performance and usability. Mol. Biol. Evol. 30: 772-780.

Kearse M., Moir R., Wilson A., Stones-Havas S., Cheung M., Sturrock S., Buxton S., Cooper A., Markowitz S., Duran C., Thierer T., Ashton B., Meintues P., DrumMOND A. 2012: Geneious Basic: an integrated and extendable desktop software platform for the organization and analysis of sequence data. Bioinformatics 28: 1647-1649.

Khalil L.F., Polling L. 1997: Check List of the Helminth Parasites of African Freshwater Fish. University of the North, Pietersburg, $161 \mathrm{pp}$.

Khalil L.F., Thurston J.P. 1973: Studies on the helminth parasites of freshwater fishes of Uganda including the descriptions of two new species of digeneans. Rev. Zool. Bot. Afr. 87: 209-248.

De Kock K.N., Wolmarans C.T. 2008: Distribution of the pill clam Pisidium langleyanum Melvill \& Ponsonby, 1891 (Bivalvia: Sphaeriidae) in South Africa. Water S.A. 34: 623-630.

Koval V.P. 1972: [On the problem of independence of the species Allocreadium baueri Spassky et Roytman, 1960 (Trematoidea)] Vestn. Zool. 5: 56-61. (In Russian.)

Kudlai O., Scholz T., Smit N. 2018: Chapter 4.5. Trematoda. In: T. Scholz, M.P.M. Vanhove, N. Smit, Z. Jayasundera and M. Gelnar (Eds.). A Guide to the Parasites of African Freshwater Fishes. ABC Taxa, Belgium, pp. 245-268.

Kumar S., Stecher G., Tamura K. 2016: MEGA7: Molecular evolutionary genetics analysis version 7.0 for bigger datasets. Mol. Biol. Evol. 33: 1870-1874.

MANTER H.W. 1963: The zoogeographical affinities of trematodes of South American freshwater fishes. Syst. Zool. 12: 45-70.

Mashego S. 1982: A seasonal investigation of the helminth parasites of Barbus species in water bodies in Lebowa and Venda, South Africa. PhD Thesis, University of the North, Pietersburg, $195 \mathrm{pp}$.

MbahinZiReki G.B. 1987: The occurrence of Allocreadium mazoensis (Trematoda) in haplochromines of Lake Victoria. Neth. J. Zool. 37: 105-109.

Moravec F. 1977: Some digenetic trematodes from Egyptian freshwater fishes. Věstn. Českoslov. Spol. Zool. 41: 52-67.

Moravec F. 2002: External morphological differences between Crepidostomum farionis and Crepidostomum metoecus (Trematoda: Allocreadiidae), parasites of salmonids, as revealed by SEM. Folia Parasitol. 49: 211-217.

Mueller J.F., Van Cleave H.J. 1932: Parasites of the Oneida Lake fishes. Part 2. Descriptions of new species and some general taxonomic considerations, especially concerning the trematode family Heterophyidae. Roosevelt Wild Life Annals 3: 79-137.
Mwita C.J. 2014: The community of parasites infecting Clarias gariepinus in the Tanzanian waters: a case of Lake Victoria. Open J. Ecol. 4: 873-882.

Mwita C.J., Nkwengulila G. 2010: Phylogenetic relationships of the metazoan parasites of the clariid fishes of Lake Victoria inferred from partial 18S rDNA sequences. Tanz. J. Sci. 36: $47-58$.

Nation J.L. 1983: A new method using hexamethyldisilazane for preparation of soft insect tissues for scanning electron microscopy. Stain Technol. 58: 347-351.

Nei M., Kumar S. 2000: Molecular Evolution and Phylogenetics. Oxford University Press, Oxford, 333 pp.

Odening K. 1959: Über Plagiorchis, Omphalometra und Allocreadium (Trematoda, Digenea). Z. Parasitenkd. 19: 14-34.

OdHner T. 1901: Revision einiger Arten der Distomengattung Allocreadium Lss. Zool. Jahrb. 14: 483-520.

Olson P.D., Cribi T.H., Tkach V.V., Bray R.A., Littlewood D.T.J. 2003: Phylogeny and classification of the Digenea (Platyhelminthes: Trematoda). Int. J. Parasitol. 33: 733-755.

PANDE B.P. 1937: XLVII. - morphology and relationships of a new digenetic trematode from an Indian freshwater fish, Ophiocephalus punctatus. Ann. Mag. Nat. Hist. 10: 415-421.

Peters L.E. 1957: An analysis of the trematode genus Allocreadium Looss with the description of Allocreadium neotenicum sp. nov. from water beetles. J. Parasitol. 43: 136-142.

Petkevičiūté R., Stunžėnas V., Stanevičiūté G. 2012: Clarification of the systematic position of Cercariaeum crassum Wesenberg-Lund, 1934 (Digenea), based on karyological analysis and DNA sequences. J. Helminthol. 86: 293-301.

Petkevičiūté R., StunžÉnas V., Stanevičiūtė G., Sokolov S.G. 2010: Comparison of the developmental stages of some European allocreadiid trematode species and a clarification of their life-cycles based on ITS2 and 28S sequences. Syst. Parasitol. 76: 169-178.

Petkevičiūtė R., StunžĖnas V., Zhokhov A.E., Poddubnaya L.G., StAnevičIŪtė G. 2018: Diversity and phylogenetic relationships of European species of Crepidostomum Braun, 1900 (Trematoda: Allocreadiidae) based on rDNA, with special reference to Crepidostomum oschmarini Zhokhov \& Pugacheva, 1998. Parasit. Vectors 11: 530.

Platta C.S., Choudhury A. 2006: Systematic position and relationships of Paracreptotrematina limi, based on partial sequences of $28 \mathrm{~S}$ rRNA and cytochrome $\mathrm{c}$ oxidase subunit 1 genes. J. Parasitol. 92: 411-413.

RAI S.L. 1962: Studies on three new species of the genus Allocreadium Looss, 1900, from the intestine of Barbus tor (Ham.). Parasitology 52: 23-30.

Rankin J.S. 1937: New helminths from North Carolina salamanders. J. Parasitol. 23: 29-42.

Rees G. 1968: Macrolecithus papilliger sp. nov. (Digenea: Allocreadiidae, Stossich, 1904) from Phoxinus phoxinus (L.). Morphology, histochemistry and egg capsule formation. Parasitology 58: $855-878$.

Saoud M.F.A., Abdel-Hamid M.E., Ibrahim A.M. 1974: On Allocreadium sudanensis sp. nov. (Trematoda: Digenea) from a freshwater fish in the Sudan. J. Helminthol. 48: 67-72.

Shimazu T. 2016: Digeneans parasitic in freshwater fishes (Osteichthyes) of Japan VII. Allocreadiidae: Allocreadium. Bull. Natl. Mus. Nat. Sci. Ser. A 42: 55-79.

Shimazu T. 2017: Digeneans parasitic in freshwater fishes (Osteichthyes) of Japan XII. A list of the papers of the series, a key to the families in Japan, a parasite-host list, a host-parasite list, Addenda, and Errata. Bull. Natl. Mus. Nat. Sci. Ser. A 43: 129-143.

Shimazu T., Urawa S., Coria C.O. 2000: Four species of digeneans, including Allocreadium patagonicum sp. n. (Allocreadiidae), from freshwater fishes of Patagonia, Argentina. Folia Parasitol. 47: 111-117.

Skelton P. 2001: A Complete Guide to the Freshwater Fishes of Southern Africa. Struik Publishers, Cape Town, 395 pp. 
Smit N.J., Malherbe W., Hadfield K.A. 2017: Alien freshwater fish parasites from South Africa: diversity, distribution, status and the way forward. Int. J. Parasitol. Parasites Wildl. 6: 386-401.

Soldánová M., Georgieva S., Roháčová J., Knudsen R., Kuhn J.A., Henriksen E.H., Siwertsson A., Shaw J.C., Kuris A.M., Amundsen P.-A., Scholz T., Lafferty K.D., Kostadinova A. 2017: Molecular analyses reveal high species diversity of trematodes in a sub-Arctic lake. Int. J. Parasitol. 47: $327-345$.

Thatcher V.E. 2006: Amazon Fish Parasites. In: J. Adis, J.R. Arias, G. Rueda-Delgado and K.M. Wantzen (Eds.), Aquatic Biodiversity in Latin America, Second Edition. Pensoft Publishers, Sofia-Moscow, 508 pp.

Thomas J.D. 1957: A new species of the genus Allocreadium (Trematoda: Allocreadiidae) from a freshwater fish, Alestes macrolepidotus, in West Africa. J. W. Afr. Sci. Ass. 3: 1-9.
TKach V.V., Littlewood D.T.J., Olson P.D., Kinsella J.M., SWIDERSKi Z. 2003: Molecular phylogenetic analysis of the Microphalloidea Ward, 1901 (Trematoda: Digenea). Syst. Parasitol. 56: $1-15$.

VAInUtis K.S. 2020: Allocreadium khankaiensis sp. nov. and Allocreadium hemibarbi Roitman, 1963 (Trematoda: Allocreadiidae) from the Russian Far East: morphological, molecular, and phylogenetic studies. Parasitol. Int. 76: 102102.

WALLIN I.E. 1909: A new species of the trematode genus Allocreadium with a revision of the genus and a key to the subfamily Allocreadiidae. Trans. Am. Microsc. Soc. 29: 50-64.

WoRMS Editorial BoArd 2020: World Register of Marine Species, www.marinespecies.org, 08/2020.

ŽĎÁRSKÁ Z., NeBEsÁŘovÁ, J. 2004: Transmission electron microscopy of presumed sensory receptors in the forebody papillae of Crepidostomum metoecus (Digenea: Allocreadiidae). Folia Parasitol. 51: 27-32.

Cite this article as: Dos Santos Q.M., Gilbert B. M. , Avenant-Oldewage A., Dumbo J. C. 2021: Morphological and molecular description of Allocreadium apokryfi sp.n. (Digenea: Allocreadiidae) from native Labeobarbus aeneus (Cyprinidae) in South Africa, including notes on its biology, evolutionary history and an updated key of African Allocreadium. Folia Parasitol. 68: 013. 